\title{
Bioefficacy and Economics of Certain Novel Generation Insecticides against Spotted Pod Borer, Maruca vitrata (Geyer) in Greengram (Vigna radiata L.)
}

\author{
Elluru Sireesha, Gaje Singh, Rajendra Singh, Bhupendra Singh
}

10.18805/LR-4651

\begin{abstract}
Background: Spotted pod borer, Maruca vitrata, cause greater damage by attacking flowers, pods in greengram plants. This study investigates the efficacy and economics of certain novel insecticides when sprayed against spotted pod borer in green gram. Methods: The experiment was conducted at Crop Research Center, Sardar Vallabhbhai Patel University of Agriculture and Technology, Meerut, during kharif 2019 in randomized block design with eight treatments (Emamectin benzoate, Spinosad, Chlorantroniliprole, Indoxacarb, Novaluron, Profenophos, Triazophos and control) and three replications on variety SML668. Observations were taken at three, seven and eleven days after the first and second spray and the data thus recorded were analyzed.

Result: The insecticide Chlorantraniliprole 20SC @ $0.025 \mathrm{ml} /$ lit has shown the highest efficacy with low per cent pod damage (7.33) and maximum grain yield (8.61q/ ha) against $M$. vitrata from the first day of application followed by Spinosad $45 \mathrm{SC} @ 0.25 \mathrm{ml} /$ lit with pod damage of 10.67 per cent and grain yield of $5.08 \mathrm{q} /$ ha. The highest cost-benefit ratio was obtained in Emamectin benzoate treatment $(1: 8.54)$, followed by chlorantraniliprole $(1: 6.76)$.
\end{abstract}

Key words: Bioefficacy, Maruca virata, Novel generation insecticides, Spotted pod borer.

\section{INTRODUCTION}

Pulses possess a unique position in India's agricultural economy, being a major source of protein in the diet, which is often regarded as poor man's meat due to densely packed with a protein percentage of 22-24, which are almost twice that of wheat and thrice that of rice. Among them, mung bean (Vigna radiata L.) is an important pulse crop and belongs to Leguminosae. It is believed to be indigenous of central Asia and India. Similar to other pulses, mung bean is primarily grown for its protein-rich seeds where it contains $(24 \%)$ protein with a rich source of minerals, i.e., iron $(0.0073 \%)$, carotene $(0.00039 \%)$, phosphorous $(0.326 \%)$, niacin $(0.0021 \%)$ and energy $334 \mathrm{cal} / 100 \mathrm{~g}$ of mung bean (Singh et al., 2020). During the year 2018 in India, mung bean accounts for a production of 2.45 million tons with average productivity of $516 \mathrm{~kg} /$ hectare from an area of 4.75 million hectares, where it contributes about 10-13 per cent of the total pulses production of the country (Anonymous, 2018).

The average productivity of pulses is very low because of abiotic and biotic factors such as temperature, relative humidity, rainfall and diseases as well as insect pests, especially pod borers (War et al. 2017; Pandey et al. 2018). Among the pod borer complex spotted pod borer, Maruca vitrata (Crambidae: Lepidoptera) is the serious pest of grain legumes including mung bean, red bean, pigeon pea and common beans (Chandrayudu, 2008), with the grain yield losses estimated from 10 to 80 per cent in various crops (Kumar et al., 2014) where it becomes a menace especially during the flowering to pod formation stages and has been
Department of Entomology, College of Agriculture, Sardar Vallabhbhai Patel University of Agriculture and Technology, Meerut250 110, Uttar Pradesh, India.

Corresponding Author: Elluru Sireesha, Department of Entomology, College of Agriculture, Sardar Vallabhbhai Patel University of Agriculture and Technology, Meerut-250 110, Uttar Pradesh, India. Email: sirishaelluru110@gmail.com

How to cite this article: Sireesha, E., Singh, G., Singh, R., Singh, B. (2021). Bioefficacy and Economics of Certain Novel Generation Insecticides against Spotted Pod Borer, Maruca vitrata (Geyer) in Greengram (Vigna radiata L.). Legume Research. DOI: 10.18805/ LR-4651.

Submitted: 04-05-2021 Accepted: 16-08-2021 Online: 06-09-2021

reported to be a pest on 39 host plants in Asia (Yadav and Singh, 2014). Control of $M$. vitrata damage largely relies upon the availability and application of chemical insecticides. However, its effectiveness is holdback due to variable reasons like larval webbing, insecticide resistance, etc., that lowers pesticide exposure. The present study aimed to evaluate the efficacy of some novel insecticides against spotted pod borer infesting green gram.

\section{MATERIALS AND METHODS}

The experiment was conducted during kharif 2019, at Crop Research Center, Sardar Vallabhbhai Patel University of Agriculture and Technology, Meerut, Uttar Pradesh, to evaluate the efficacy of insecticides against Spotted Pod borer in green gram. The crop was grown with a spacing of 
Bioefficacy and Economics of Certain Novel Generation Insecticides against Spotted Pod Borer, Maruca vitrata (Geyer)......

$30 \mathrm{~cm} \times 10 \mathrm{~cm}$ with three replications in a randomized block design. The incidence of spotted pod borer was monitored at weekly intervals to observe the economic threshold level. Application of insecticides was made with a motor-operated knapsack sprayer twice during the crop period, one at the flowering stage and another at 15 days after the first spray. Based on the active ingredient and required concentration of the insecticide, the insecticide's desired amount is measured and subsequently mixed with water (500 L/ ha). Population density of spotted pod borer, $M$. vitrata was recorded by randomly picking ten plants per plot from each treatment one day before spray and three, seven and eleven days after first and second sprays, respectively and analyzed.

Per cent infestation of pods was also considered where randomly 100 pods were collected from each treatment before harvesting. All the pods showing pod damage were counted and per cent pod damage was calculated based on the following formula:

Per cent pod damage $=$

$\frac{\text { Total number of damaged pods }}{\text { The total number of pods observed }} \times 100$

The grain yield, economics and cost-benefit ratio of all the insecticidal treatments were calculated.

\section{RESULTS AND DISCUSSION}

The results of the experiment are presented in Table 1, where the larval population before spraying was uniformly distributed all over the experimental field and it ranged from 13.33 to 14.00 larvae/ ten plants. All the treatments were effective against Maruca when compared with the untreated control. The data at 3 DAS showed that the minimum larval population of $M$. vitrata was noticed in the treatment of chlorantraniliprole $10 \mathrm{~g}$ a.i / ha (3.33 larvae / ten plants) followed by Spinosad $56 \mathrm{~g}$ a.i / ha (4.33 larvae / ten plants) and the maximum larval population was found in treatment of triazophos 400 a.i / ha (7.33 larvae/ ten plants). At 7DAS same trend was observed and that the minimum larval population of $M$. vitrata was noticed in the treatment of chlorantraniliprole $10 \mathrm{~g}$ a.i / ha (2.67 larvae / ten plants) followed by Spinosad $56 \mathrm{~g}$ a.i / ha (3.00 larvae / ten plants) and the maximum was found in triazophos $400 \mathrm{a} . \mathrm{i} / \mathrm{ha}(6.67$ larvae/ ten plants). The data recorded at 11 DAS showed the minimum larval population in treatment chlorantraniliprole $10 \mathrm{~g}$ a.i / ha (3.67 larvae / ten plants) followed by Spinosad $56 \mathrm{~g} \mathrm{a.i} \mathrm{/} \mathrm{ha} \mathrm{(4.00} \mathrm{larvae} \mathrm{/} \mathrm{ten} \mathrm{plants)} \mathrm{and} \mathrm{the} \mathrm{maximum}$ larval population was recorded in treatment of triazophos 400 a.i / ha (10.00 larvae/ ten plants).

The data of the second spray revealed that the larval population during the 3DAS was ranged from 1.67 to 17.33 and it follows the same trend as the first spray. The treatment chlorantraniliprole $10 \mathrm{~g}$ a.i / ha (1.67 larvae / ten plants) showed minimum larval population and was followed by treatment of Spinosad $56 \mathrm{~g}$ a.i / ha (2.00 larvae / 10 plants) and the maximum population was noticed in -triazophos 400 a.i / ha (6.00 larvae/ plant). The treatments comprises of chlorantraniliprole $10 \mathrm{~g}$ a.i / ha and Spinosad $56 \mathrm{~g}$ a.i / ha has showed minimum larval population of 1.00 larvae / ten plants, 1.33 larvae / ten plants, respectively followed by maximum larval population of treatment-triazophos 400 a.i / ha with 4.00 larvae/ ten plant at 7 DAS. At 11 DAS, the treatments chlorantraniliprole $10 \mathrm{~g}$ a.i / ha and Spinosad $56 \mathrm{~g}$ a.i / ha has shown minimum larval population of 0.33 larvae / ten plants and 0.67 larvae / ten plants, respectively whereas maximum larval population was noticed in treatment comprises of triazophos 400 a.i / ha (2.67 larvae/ ten plants). On the basis of present trial it can be concluded that the treatment chlorantraniliprole $10 \mathrm{~g}$ a.i / ha was most effective in managing the Maruca population and was followed by Spinosad $56 \mathrm{~g}$ a.i / ha. Among all the treatments, triazophos was found least effective in managing the larval population. Other workers also reported chlorantraniliprole as most effective against this pest (Mahalakshmi et al. (2013); Swami et al. (2017); Parvina et al. (2018). Further, Swathi et al. (2018) also reported that treatment spinosad was effective against the Maruca. Thus, support the present findings.

The data presented in Table 1 also revealed per cent pod damage to the mung bean due to the legume pod borer ranging from 7.33 to 22.67 in the various treatments, while the maximum pod damage was noticed in the control plot with 28.67 per cent. Among all the treatments, Chlorantraniliprole 20SC recorded with minimum pod damage of 7.33 per cent and followed by Spinosad 45 SC, Emamectin benzoate 5SG, Indoxacarb 14.5SC, Novaluron and Profenophos and Triazophos 40EC @ $4.0 \mathrm{gm}$ per liter of water with 10.67, 11.67, 14.00, 16.67, 18.67 and 22.67 per_cent pod damage, respectively. These findings are supported by Kumar et al. (2015) reported that chlorantraniliprole 18.5 SC $30 \mathrm{~g}$ a.i/ ha recorded mimimum larval incidence of Helicoverpa armigera in Red gram. Parvina et al. (2018), who observed that chlorantraniliprole 18.5 SC 0.01 per cent recorded minimum pod damage against lepidopteran pests and registered as the most effective treatment in managing lepidopteran pests. Regmi et al. (2014) also found similar results with emamectin benzoate 5 SG @ 0.25 g per litre decreased pod damage (5.76 per cent) and increased net yield of green pod on yard long bean. Singh and Singh (2017) also reported that spinosad $60 \mathrm{~g}$ a.i./ ha and emamectin benzoate $8 \mathrm{~g}$ a.i./ ha were the most effective treatments in reducing $M$. vitrata larval population on green gram.

The data on grain yield of different insecticidal treatments can also be obtained from Table 1 revealed that the maximum grain yield of $8.61 \mathrm{q} /$ ha was recorded in Chlorantraniliprole $20 \mathrm{SC}$, which is superior over all other treatments and followed by Emamectin benzoate 5 SG, Spinosad 45 SC, Indoxacarb 14.5 SC, Novaluron 10 EC, Profenophos 50 EC and Triazophos $40 \mathrm{EC}$ with grain yield of $7.77,6.94,5.00,4.44,3.61$ and $3.33 \mathrm{q} /$ ha, respectively. The lowest grain yield with $2.22 \mathrm{q} /$ ha was obtained in untreated control compared with all other treatments. The 


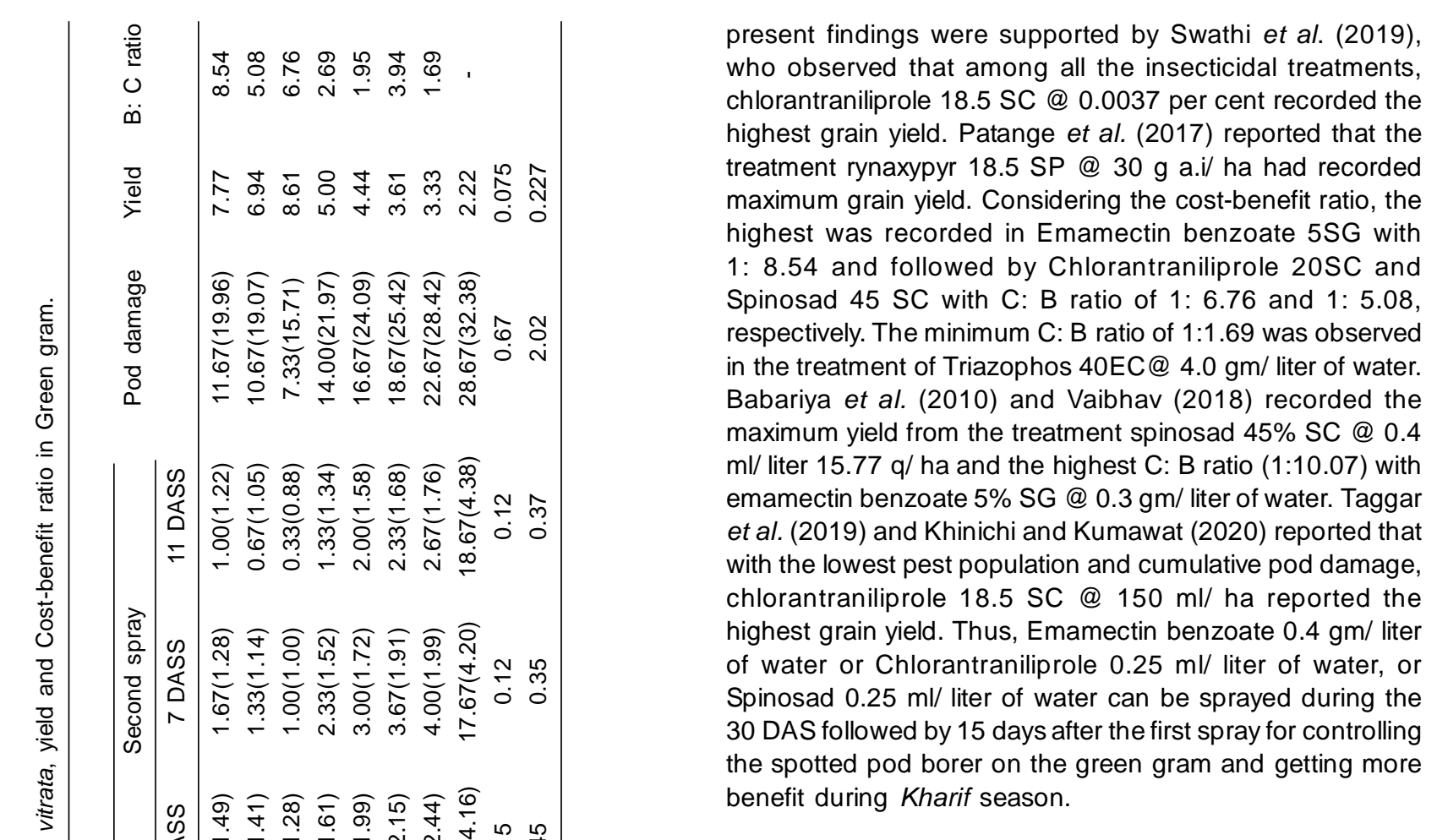

\section{CONCLUSION}

Many of the new molecules have outstanding toxicological profiles, unlike traditional ones and are generally recognized as effective compounds against Green gram pest. Chlorantraniliprole, Spinosad and Emamectin benzoate are all effective against $M$. vitrata field spray control shortly after application, but the triazophos is not as much effective when compared with other compounds.

\section{REFERENCES}

Anonymous (2018). All India area, production and productivity of Green gram and Pulses, Ministry of Agriculture and Farmers Welfare, Govt. of India.

Babariya, P.M., Kabaria, B.B., Patel, V.N. and Joshi, M.D. (2010). Chemical control of gram pod borer, Helicoverpa armigera infesting pigeonpea. Legume Research (33): 224-226.

Chandrayudu, E., Srinivasan, S. and Rao, N.V. (2008). Evaluation of certain newer insecticides against spotted pod borer, Maruca vitrata (Geyer) on cowpea (Vigna unguiculata). Current Biotica. 2(2): 240-243.

Khinichi, S.K. and Kumawat, K.C. (2020). Bioefficacy of chlorantraniliprole 18.5 SC against pod borer, Helicoverpa armigera and pod fly, Melanagromyza obtusa in pigeonpea, Cajanus cajan. Legume Reseach.

Kumar, S.S., Durairaj, C., Ganapathy, N. and Mohankumar, S. (2014). Field efficacy of newer insecticides against Legume pod borer, Maruca vitrata in greengram. Indian Journal of Plant Protection. 42(1): 1-5.

Mahalakshmi. S. M., Rama Rao, C.V., Adinarayana, M., Sateesh Babu, J. and Rao, K.Y. (2013). Evaluation of collagen against legume pod borer, Maruca vitrata (Geyer) (Lepidoptera: Pyralidae) on the black gram, International Journal of Plant, Animal and Environmental Sciences. 3(4): 51-54. 
Pandey, A.K., Burlakoti, R.R., Kenyon, L. and Nair, R.M. (2018). Perspectives and challenges for sustainable management of fungal diseases of mungbean (Vigna radiate): A Review. Frontier of Environmental Science. 53(6).

Parvin, P.S. N,.Barde, S.R. Kamdi, N.V., Lavhe, R.W., Gawande and Masal, R.G. (2018). Efficacy of some newer insecticides in comparison with botanicals against pod borer complex in pigeon pea. International Journal of Current Microbiology and Applied Sciences. 6: 911-919.

Patange, N.R. and Chiranjeevi (2017). Bioefficacy of newer insecticides against Pigeon pea [Cajanus cajan (L.) Millsp.] pod borers. Journal of Entomology and Zoology Studies. 5(3): 28-31.

Regmi, R., Tiwari, S. and Thapa, R.B (2014). Ecofriendly management of spotted pod borer (Maruca vitrata) on Yardlong Bean in Chitwan, Nepal. International Journal of Research. 1(6): 386-394.

Sambathkumar, S., Durairaj, C., Ganapathy, N. and Mohankumar, N. (2015). Field evaluation of newer insecticides molecules and botanicals aganist pod borers of red gram. Legume Research. (38): 260-267.

Singh, B.K., Pandey, Rakesh, Singh, A.K., Mishra, M.K., Singh, S.K. and Gupta, R.P. (2020). Field efficacy of new generation insecticides for the management of spotted pod borer, Maruca vitrata in cowpea. International Journal of Plant Protection. 13(1): 36-39.

Singh, S.K. and Singh, P.S. (2017). Bioefficacy of certain insecticides and biopesticides against spotted pod borer, Maruca vitrata infesting Greengram. International Journal of Agriculture, Environment and Biotechnology. 10(6): 785-792.
Swami, H., Ameta, O.P. and Lekha. (2015). Bioefficacy of novel insecticides against pod borer (Helicoverpa armigera) in pigeonpea. Legume Research. (40): 756-761.

Swathi, K.K., Pandya, H.V. and Swarnalatha, B. (2018). Efficacy of the different combination of insecticides against Spotted pod borer in Cowpea (Vigna ungiculata). International Journal of Chemical Studies. 6(3): 1199-1202.

Swathi, K., Ramu, P.S., Dhurua, S. and Suresh, M. (2019). Field evaluation of newer insecticides against spotted pod borer, Maruca vitrata (Geyer), on black gram (Vigna mungo L.) in north coastal Andhra Pradesh. An International Research Journal of Pure and Applied Chemistry. 18(2): 1-9.

Taggar, G.K., Singh, R., Randhawa, H.S. and Cheema, H.K. (2019). Novel insecticides for the management of pod borer complex in pigeonpeacrop. Legume Research. 1-7.

Vaibhav, V. (2018). Germplasm screening and evaluation of biorational insecticides against major pod borers in pigeon pea. (Ph.D.) thesis submitted to SVPUA and T, Meerut (U.P.).

War, A.R., Murugesan, S., Boddepalli, V.N., Srinivasan, R. and Nair, R.M. (2017). Mechanism of Resistance in Mung bean (Vigna radiata) to Bruchids, Callosobruchus spp. (Coleoptera: Bruchidae). Frontal of Plant Sciences. 1031(8).

Yadav, N.K. and Singh, P.S. (2014). Bio-efficacy of chemical insecticides against spotted pod borer, Maruca testulalis (Geyer) on mung bean. International Journal of Agriculture, Environment and Biotechnology. 7(1): 187-190. 